increased by 60 p. 100 compared to the control value). The noticeable differences between the effects of WB and RB diets on Ca-P metabolism might be attributed to the 16-times higher dietary phytase activity of RB. However, other variables such as trial length or percentage of bran incorporation might explain these differences.

Our results clearly demonstrate that high dietary phytase levels or rich phytase by-products lead to a better $P$ utilization. A reduction of requirements for inorganic $P$ might save money since this $\mathrm{P}$ is still one of the most expensive feed ingredient in pig feeding.

\title{
Comparative efficiency of four iron dextran injectable solutions
}

\section{H. BRUGERE}

\author{
Ecole Nationale Vétérinaire, Chaire de Physiologie, 94700 Maisons-Alfort
}

A trial was made to compare four iron dextran solutions in 209 piglets belonging to 23 litters of 9 and 10 piglets and randomly allotted to one of the five treatments : A : $10 \mathrm{p}$. 100 iron dextran $(2 \mathrm{ml})$; B : 20 p. 100 gleptoferron $(1 \mathrm{ml}), \mathrm{C}: 20$ p. 100 iron dextran $(1 \mathrm{ml}), \mathrm{D}:$ another 20 p. 100 iron dextran preparation $(1 \mathrm{ml}), \mathrm{E}:$ control (no iron). Injections were made via the intramuscular route on the first day of life. At the end of the third week blood parameters were measured. Growth and feed conversion ratio were studied up to 10 th week.

At three weeks of age, results of blood analyses were as follows: red blood cell count $(\mathrm{RBC})=6.23-5.87-6.09-6.03$ and 5.06 millions $/ \mu \mathrm{l} ;$ hemoglobin $=11.75-11.19-11.64$ -11.56 and $6.52 \mathrm{~g} / 100 \mathrm{ml}$; hematocrit $=40.49-38.0-39.80-39.52$ and $25.84 \mathrm{p}$. 100. Live weights were $6.59-6.76-6.64-6.67$ and $4.96 \mathrm{~kg}$. After weaning, growth rate and daily mean gain remained higher in treated animals.

No difference was noted in the efficiency of the four treatments. Iron concentration (10 or 20 p. 100) had no effect on measured parameters. In contrast, blood parameters and performance were higher in treated animals than in controls.

\section{Influence of gestation and lactation food supply on the performance of sows fed a maize-based diet}

\author{
J. CASTAING ${ }^{(1)}$, R. COUDURE ${ }^{(1)}$, D. CAMBEILH ${ }^{(1)}$, M. LEUILlet $^{(2)}$
}

(1) Association Générale des Producteurs de Maïs, 122, boulevard Tourasse, 64000 Pau (2) Institut Technique des Céréales et Fourrages, 8, avenue du Président-Wilson, 75116 Paris

Three gestation and lactation diets based on maize were studied. In treatments I and II the diets consisted of maize, barley, bran and soybean meal. In treatment III they only included maize supplemented with soybean meal. During gestation, treatment I supplied $280 \mathrm{~g}$ protein and treatments II and III, $330 \mathrm{~g}$ in early gestation and $400 \mathrm{~g}$ in late gestation (the last month). Digestible energy supply was respectively 7,700 kcal or 7,700 kcal and 9,300 in late gestation. The dietary supply remained constant whatever the parity or the condition of the sow. During lactation, treatment I supplied $150 \mathrm{~g}$ protein $/ \mathrm{kg}$ of diet, treatments II and III, $180 \mathrm{~g}$.

The experimental herd of 168 Large-White sows was kept in batches with weaning of piglets at 28 days of age and a weaning-mating interval shorter than 6 days, i.e. $2.48 \mathrm{littering} / \mathrm{sow} / \mathrm{year}$. Results concerned 350 litters per treatment. Gilts were mated at 220 days of age with a mean live weight of $136 \mathrm{~kg}$. 
This experiment demonstrated the beneficial effect of increasing dietary supplies during pregnancy and lactation on numerical productivity of sows and weight of piglets. The effect of increasing the protein level (from 280 to $350 \mathrm{~g}$ crude protein on an average per day of gestation and from 12 to $16 \mathrm{~g}$ of lysine and during lactation from 850 to $1000 \mathrm{~g}$ of crude protein and from 40 to $55 \mathrm{~g}$ of lysine for a litter of 9 piglets) cannot be singled out from the effect of a higher energy supply in late gestation $(9,300 \mathrm{kcal} \mathrm{DE} /$ day versus $7,700 \mathrm{kcal} \mathrm{DE} /$ day). The same level of performance was not reached with monocereal diets composed of maize and soybean meal without ballast supplementation as compared to mixed feeds.

\title{
Effect of environmental temperature on energy expenditures of the pregnant sow : Interaction with the nature of the diet (wheat straw, lucerne meal)
}

\author{
J. NOBLET, J.Y. DOURMAD, S. DUBOIS, J. LE DIVIDICH
}

INRA, Station de Recherches Porcines, Saint-Gilles, 35590 L'Hermitage

Two trials were made to quantify the effects of environmental temperature on the increased energy requirements of pregnant sows and to measure the nutritive value of wheat straw and lucerne meal as affected by environmental temperature.

Trial 1: Four multiparous pregnant sows were kept in respiratory chambers for three consecutive 8-day periods at temperatures of $20^{\circ} \mathrm{C}, 14^{\circ} \mathrm{C}$ and $8{ }^{\circ} \mathrm{C}$, respectively. During each period they were subjected to a high $(2.7 \mathrm{~kg} /$ day $)$ and to a low $(2.1 \mathrm{~kg} / \mathrm{d})$ feeding level.

Trial 2: Twelve multiparous pregnant sows were assigned to one of the three dietary treatments : 1) $2.6 \mathrm{~kg}$ of control diet ;2) $2.6 \mathrm{~kg}$ of control diet $+600 \mathrm{~g}$ of straw ; 3) $2.6 \mathrm{~kg}$ of control diet $+600 \mathrm{~g}$ of lucerne meal. They were kept in respiratory chamber at environmental temperatures varying successively from $23^{\circ} \mathrm{C}$ to $8{ }^{\circ} \mathrm{C}$ and from $8{ }^{\circ} \mathrm{C}$ to $23^{\circ} \mathrm{C}$ by $3{ }^{\circ} \mathrm{C}$ stages (three days at each stage).

Results showed that in the pregnant sow the critical temperature was close to $23{ }^{\circ} \mathrm{C}$ and was dependent on the level of feed intake. An environmental temperature of $8{ }^{\circ} \mathrm{C}$ (relative to $20^{\circ} \mathrm{C}$ ) required an additional food supply of 930 and $660 \mathrm{~g} / \mathrm{d}$ for the high and low level of trial 1, respectively.

Maintenance requirements of multiparous pregnant sows were similar to those of primiparous (100 to $105 \mathrm{kcal} \mathrm{ME} / \mathrm{kg}^{0.75}$ ) and were affected by the environmental temperature and the physical activity of the animals.

The DE and ME contents of straw and lucerne meal were 1,024 and 2,042 kcal DE and 1,006 and $1,775 \mathrm{kcal} \mathrm{ME} / \mathrm{kg} \mathrm{DM}$, respectively. The marginal efficiency of $\mathrm{ME}$ was dependent on the environmental temperature and was close to $100 \mathrm{p}$. 100 at lower temperatures, which indicates a good utilization of raw materials for thermoregulation. 